\title{
In vitro folate deficiency induces apoptosis by a p53, Fas (Apo-1, CD95) independent, bcl-2 related mechanism in phytohaemagglutinin-stimulated human peripheral blood lymphocytes
}

\author{
Hui-Li Lin ${ }^{2}$, Chung-Jern Chen ${ }^{1}$, Wen-Chan Tsai ${ }^{1}$, Jeng-Hsien Yen ${ }^{1}$ and Hong-Wen Liu ${ }^{1}{ }^{*}$ \\ ${ }^{1}$ Division of Allergy, Immunology, and Rheumatology, Department of Internal Medicine, College of Medicine, Kaohsiung Medical \\ University, Kaohsiung, Taiwan, ROC \\ ${ }^{2}$ Graduate Institute of Medicine, College of Medicine, Kaohsiung Medical University, Kaohsiung, Taiwan, ROC
}

(Received 30 January 2005 - Revised 26 June 2005 - Accepted 14 July 2005)

\begin{abstract}
In vitro folate deficiency is associated with $\mathrm{S}$ phase accumulation and apoptosis in various cell types. To investigate the role of p53 and two apoptosis-related molecules, bcl-2 and Fas antigen (Apo-1, CD95), in the mechanism whereby folate-deficient lymphocytes accumulate and undergo apoptosis in the S phase, normal human peripheral blood lymphocytes were cultured for 3-9 d in control medium or in specially ordered and formulated HAM's F-10 medium lacking folic acid, thymidine and hypoxanthine. Cells were stimulated with phytohaemagglutinin for the final $72 \mathrm{~h}$ prior to harvesting. The results indicate that p53 expression was downregulated in folate-deficient lymphocytes when compared with the control lymphocytes during the relevant period of S phase accumulation and apoptosis. In addition, folate deficiency was also found to downregulate IL-2, Fas antigen and bcl-2 expression, in terms of either mRNA or protein levels. The downregulation of Fas antigen suggests that folate deficiency-induced apoptosis probably does not occur via the Fas pathway. As IL-2 is a known inducer of bcl-2, and the downregulation of bcl-2 induces apoptosis, the downregulation of IL-2 and bcl-2 is suggested to play an important role in apoptosis. The complete rescue of folate-deficient lymphocytes from apoptosis was achieved by folic acid, thymidine or hypoxanthine alone or thymidine and hypoxanthine in combination. These results suggest that IL-2 depletion by folate deficiency in lymphocytes reduces the bcl-2 level, thereby triggering deoxynucleoside triphosphate pool imbalance and p53-independent apoptosis.
\end{abstract}

Folate deficiency: Apoptosis: p53: bcl-2

Folate, in the form of tetrahydrofolate coenzymes, is an essential carrier of methyl groups within cells. These act as either donors or receivers of one-carbon moieties in a variety of reactions involved in the synthesis of thymidylate and purines, and in the methylation of cytosine in DNA (Shane \& Stockstad, 1985). Thus, folate deficiency can lead to an alternation in DNA by limiting the number of intracellular thymidylate, purine deoxynucleotides or methyl groups available for cytosine methylation. Clinically, a deficiency of this vitamin is associated with an increased risk of certain types of cancer (Rosenberg \& Mason, 1989; Freudenheim et al. 1991) and many other diseases, including megaloblastic anaemia, infant neural tube defects (Smithells et al. 1976; Fleming \& Copp, 1998) and CHD (Bunout et al. 2000; Michalis et al. 2001).

Although the mechanisms by which folate deficiency causes these diseases remains unclear, it has been demonstrated that in vitro folate deficiency is associated with $\mathrm{S}$ phase accumulation in various cell types (Huang et al. 1999; Koury et al. 2000), gene instability (Duthie \& Hawdon, 1998; Duthie et al. 2002) and DNA damage (James et al. 2003; Courtemanche et al. 2004). In addition to genetic damage, it is well established that folate deficiency induces programmed cell death, or apoptosis, a process marked by cell shrinkage, membrane blebbing, chromatin condensation and eventual internucleosome DNA cleavage (Huang et al. 1999). A critical regulator of the cellular response to DNA damage is the transcription factor encoded by the p53 tumour-suppressor gene (Donehower \& Bradley, 1993; Zambetti \& Levine, 1993). Normal cells express very low levels of p53 protein, but its level rises rapidly after irradiation or exposure to agents that damage DNA (Maltzman \& Czyzyk, 1984; Kuerbitz et al. 1992; Lowe et al. 1993). These genotoxic insults are known to induce apoptotic cell death through p53-dependent pathways, yet Strasser et al. demonstrated that genotoxic insults could also induce apoptosis in activated T-cells obtained from p53 $3^{-1-}$ animals (Strasser et al. 1994). This indicates that, in certain settings, cell death induced by DNA damage can also be mediated by a $\mathrm{p} 53$-independent mechanism.

In spite of an earlier study showing that erythroblasts undergoing apoptosis due to intracellular folate deficiency had increased levels of p53 protein, Koury et al. showed, in a more recent study, that the $\mathrm{S}$ phase accumulation and increased rate of apoptosis during folate deficiency were p53-independent (Koury et al. 2000). The apoptosis of HepG2 cells during folate deficiency has also been shown to be independent of increased p53 expression (Huang et al. 1999). 
Dietary folate deficiency has been shown to induce DNA strand breaks within a highly conserved region of the p53 tumour-suppressor gene in rat liver (Pogribny et al. 1995) and a decreased steady state of p53 transcript in rat colon (Kim et al. 2000). However, the level of p53 transcript in folate-deficient human lymphocytes has not been reported. To obtain more information on folate deficiency-induced apoptosis, two apoptosis-related molecules, bcl-2 and Fas antigen (Apo-1, CD95) were studied.

The present in vitro study of folate deficiency in normal human peripheral blood lymphocytes (PBL) was used to address the following questions: (1) Is the apoptosis related to folate deficiency p53 dependent? (2) Can the addition of folate, hypoxanthine and thymidine rescue folate-deficient lymphocytes from apoptosis? (3) Are the apoptosis-related molecules bcl-2 and Fas expressed in folate-deficient lymphocytes?

\section{Methods}

\section{Materials}

Folate (pteroylmonoglutamic acid), amino acids, nucleosides, nucleotides and other chemical compounds were purchased from Sigma Chemical (St. Louis, MO, USA). Modified standard HAM's F-10 medium with L-glutamine but without ribosides, ribotides, deoxyribosides, deoxyribotides, glycine or folic acid was specially ordered from and formulated by Biological Industries (Beit Haemek, Israel). Fetal calf serum (FCS) also came from Biological Industries. Penicillin and streptomycin were purchased from GIBCO Laboratories (Grand Island, NY, USA).

\section{Cell preparation}

Approval for the study was obtained from Kaoshiung Medical University Human Ethics Committee. Human peripheral blood mononuclear cells were isolated from healthy volunteers by density gradient centrifugation using a Ficoll-Paque cushion (Amersham Biosciences, Uppsala, Sweden). These cells were plated on Petri dishes at $37^{\circ} \mathrm{C}$ in a $5 \% \mathrm{CO}_{2}$ and $99 \%$ humidity incubator for $2 \mathrm{~h}$; non-adherent cells were collected as PBL, washed and then resuspended in control (CM) or folate-deficient medium (FDM) at a concentration of $1 \times 10^{6} / \mathrm{ml}$. Viability was assessed by trypan blue exclusion. This viability was over $90 \%$ in CM or FDM. For stimulation, $10 \mathrm{ng} / \mathrm{l}$ phytohaemagglutinin (PHA) was added.

\section{Culture medium and cell culture}

Standard HAM's F-10 medium contains folic acid $(0.88 \mu \mathrm{g} / \mathrm{ml})$, thymidine $(8.7 \mu \mathrm{g} / \mathrm{ml})$ and hypoxanthine $(4.9 \mu \mathrm{g} / \mathrm{ml})$. The medium was specially ordered and formulated without folic acid, thymidine or hypoxanthine in order to stress the availability of both precursors for the de novo pathway of nucleotide synthesis (folate derivatives) and precursors for the salvage pathway biosynthesis (thymidine, hypoxanthine). To minimise any exogenous folate source, FCS was dialysed at $4^{\circ} \mathrm{C}$ for $16 \mathrm{~h}$ against $6 \times 10$ volumes of sterile PBS. Using this procedure, serum complement contributed virtually no folic acid (Huang et al. 1999) and less than $1 \mu \mathrm{mol} / \mathrm{l}$ hypoxanthine and thymidine.

FDM was designated as folate-deficient HAM's F-10 medium supplemented with $10 \%$ dialysed FCS. This FDM contained less than $1 \mathrm{ng} / \mathrm{ml}$ folate as contributed by FCS. CM was standard F-10 medium supplemented with $10 \%$ dialysed FCS. Lymphocytes cultured in FDM and stimulated with PHA were designated as folate-deficient cells. The culture in this condition was designated the folate-deficient culture. Cells cultured in $\mathrm{CM}$ and stimulated with PHA were referred to as control cells. The culture under this condition was designated the control culture. For the culture, the PBL were allowed to grow in fortyeight- or ninety-six-well flat-bottom microtiter plates in triplicate at a concentration of $1 \times 10^{6} / \mathrm{ml} \mathrm{CM}$ or FDM for 3-9d. Cells were stimulated by PHA for the final $48-72 \mathrm{~h}$ prior to harvesting. The harvested cells were used for following experiments.

\section{Determination of intracellular folate concentration}

Intracellular folate levels were determined by a folic acid determination kit and device (IMMULITE 2000; Diagnostic Products Corporation, Los Angeles, CA, USA). This procedure is a solid-phase, competitive-binding chemiluminescent immunoassay. Cells were lysed by brief sonication in a lysis buffer containing $20 \mathrm{~g} / \mathrm{l}$ sodium ascorbate, $50 \mathrm{~mm}$-HEPES, $50 \mathrm{~mm}$-2-(N-cyclohexylamino)ethanesulfonic acid and $14 \mu \mathrm{g} / \mathrm{ml} \mathrm{L}$-2-mercaptoethanol. The supernatant was collected by centrifugation and incubated first with ligandlabelled folic acid and $2 \mathrm{~mm}$-dithiothretol at $37^{\circ} \mathrm{C}$ for $30 \mathrm{~min}$, and then with $\mathrm{NaCl} / \mathrm{KCN}$. The treated sample was transferred to a fresh tube containing folate-binding protein and folate-binding protein antibody-coated polystyrene beads, and was then incubated at $37^{\circ} \mathrm{C}$ for another $30 \mathrm{~min}$. The beads were washed to remove free folic acid and alkaline phosphatase-labelled anti-ligand, which specifically binds to the ligand-labelled folate that was added to the reaction.

After removal from the unbound alkaline phosphatase conjugate by centrifugation, the sample was incubated with the chemiluminescent substrate (a phosphate ester of adamantyl dioxetane) at $37^{\circ} \mathrm{C}$ for $5 \mathrm{~min}$, during which the substrate underwent hydrolysis to yield an unstable intermediate that emitted light. The amount of light, which is inversely proportional to the concentration of folic acid in the sample, was measured using IMMULITE 2000, and the concentration of folic acid was calculated using a standard curve.

\section{Analysis of cell cycle phase by flow cytometry}

Harvested cells were fixed in ice-cold $70 \%$ ethanol at $4^{\circ} \mathrm{C}$ for $30 \mathrm{~min}$. After centrifugation, the cell pellets were washed and resuspended in PBS. Cells were then treated with ribonuclease A $(25 \mathrm{mg} / \mathrm{l})$ and $0.5 \%$ Triton $\mathrm{X}-100$ at $37^{\circ} \mathrm{C}$ for $60 \mathrm{~min}$. Cellular DNA was stained with propidium iodide $(50 \mathrm{mg} / \mathrm{l})$ for $30 \mathrm{~min}$. After centrifugation, the pellets were resuspended in PBS. The cellular DNA in $10^{4}$ cells was analysed in an Elite-ESP flow cytometer (Beckman Coulter, Miami, FL, USA) and fixed with an argon laser set at $488 \mathrm{~nm}$. Cell debris and doublets were excluded. The percentage of three phases in the cell cycle was determined by the Multicycle DNA analysis software program (Beckman Coulter, Miami, FL, USA).

\section{Analysis of apoptosis with propidium iodide staining by flow cytometry}

Harvested cells were stained with hypotonic fluorochrome solution containing $25 \mathrm{mg} / \mathrm{l}$ propidium iodide, $0.1 \%$ Triton X-100 and $0.1 \%$ sodium citrate in PBS for $30 \mathrm{~min}$, washed in PBS and fixed with $4 \%$ paraformaldehyde for $30 \mathrm{~min}$. After centrifugation, the pellet was resuspended in PBS. The cellular DNA in $10^{4}$ cells was analysed by Elite-ESP flow cytometry. The percentage of apoptosis was determined by E4win-ESP analysis software program. 
Rescue from apoptosis by Annexin V assay

At $0 \mathrm{~h}$ of culture, folic acid, thymidine and/or hypoxanthine alone, or a combination of thymidine and hypoxanthine, was added to the medium. Cells were harvested at days 0, 4, 5 and 6, washed in PBS and incubated in a binding buffer containing Annexin $\mathrm{V}$-fluorescein and propidium iodide for $15 \mathrm{~min}$ at room temperature. After centrifugation, the pellets were resuspended in PBS. A total of $10^{4}$ cells were analysed by Elite-ESP flow cytometry. The percentage of apoptosis was determined by E4win-ESP analysis software program.

\section{RT-PCR for mRNA expression of bcl-2 Fas/Apo-1/CD95 and IL-2}

Total RNA was extracted from $5 \times 10^{6}$ cells incubated and stimulated with PHA in CM or FDM for $3 \mathrm{~d}$ using REzol $\mathrm{C} \& \mathrm{~T}$ (Promega, Madison, WI, USA) according to the manufacturer's instructions. Reverse transcription was performed with $1 \mu \mathrm{g}$ RNA, $20 \mu$ l reaction reagent containing $5 \mathrm{~mm}-\mathrm{MgCl}_{2}, 1 \mathrm{mmol} / \mathrm{l}$ dNTP mixture, $62.5 \mathrm{U}$ RNase inhibitor, $0.5 \mu \mathrm{g}$ oligo(dT) $)_{15}$ primer and $15 \mathrm{U}$ avian myeloblastosis virus $\mathrm{RT}$ in reverse transcription buffer $\left(10 \mathrm{mmol} / \mathrm{l}\right.$ Tris- $\mathrm{HCl}\left(\mathrm{pH} 9.0\right.$ at $\left.25^{\circ} \mathrm{C}\right), 50 \mathrm{mmol} /$ $1 \mathrm{KCl}, 0.1 \%$ Triton $\mathrm{X}-100)$. The mixture was incubated at $42^{\circ} \mathrm{C}$ for $15 \mathrm{~min}$, followed by $99^{\circ} \mathrm{C}$ for $5 \mathrm{~min}$ and $4^{\circ} \mathrm{C}$ for $5 \mathrm{~min}$. All reagents used in the cDNA synthesis were included from the manufacturer's instructions (Promega).

After reverse transcription, $0.625 \mathrm{U}$ Taq DNA polymerase, $1.5 \mathrm{mmol} / \mathrm{l} \mathrm{MgCl}_{2}, 0.8 \mathrm{mmol} / 1 \mathrm{dNTP}$ and $50 \mathrm{pmol} / 1$ of each primer in PCR buffer were added to the cDNA mixture, the final volume being $50 \mu \mathrm{l}$. After denaturation at $95^{\circ} \mathrm{C}$ for $5 \mathrm{~min}$, 30 cycles of $\beta$-actin amplification were performed at $94^{\circ} \mathrm{C}$ for $45 \mathrm{sec}, 60^{\circ} \mathrm{C}$ for $45 \mathrm{sec}$ and $72^{\circ} \mathrm{C}$ for $1.5 \mathrm{~min} /$ cycle; bcl- 2 amplification at $94^{\circ} \mathrm{C}$ for $45 \mathrm{sec}, 52^{\circ} \mathrm{C}$ for $45 \mathrm{sec}$ and $72^{\circ} \mathrm{C}$ for $1.5 \mathrm{~min} /$ cycle; and Fas and IL-2 amplification at $94^{\circ} \mathrm{C}$ for $45 \mathrm{sec}, 55^{\circ} \mathrm{C}$ for $45 \mathrm{sec}$ and $72^{\circ} \mathrm{C}$ for $1.5 \mathrm{~min} /$ cycle.

The primers for $\beta$-actin message amplification were $5^{\prime}$-ATCTGGCACCACACCTTCTACAATGAGCTGCG-3' (sense) and 5'-CGTCATACTCCTGCTTGCTGATCCACATATGC-3' (antisense). The primers for bcl-2 message amplification were $5^{\prime}$-GGTGCCACCYGYGGTCCACCTG - $3^{\prime}$ (sense) and $5^{\prime}$-CACTTGTGGCTCAGATAGG- $3^{\prime}$ (antisense). The primers for Fas message amplification were $5^{\prime}$-TTATCGTCCAAAAGTGTTA - $3^{\prime}$ (sense) and $5^{\prime}$-TTCTGTTCTGCTGTGTCTTG $-3^{\prime}$. The primers for IL-2 message amplification were $5^{\prime}$-ATGTACAGGATGCAACTCCTGTCTT- $3^{\prime}$ (sense) and 5'-CTCAGT GTTGAGATGATGCTTTGAC- $3^{\prime}$ (antisense). The message amplifications of $\beta$-actin, bcl2 , Fas and IL-2 were electrophoresed on a $2 \%$ agarose minigel at $100 \mathrm{~V}$ for $30 \mathrm{~min}$ and visualised with ethidium bromide staining under UV illumination. Multimers of $100 \mathrm{bp}$ DNA ladder plus were used as markers (MBI Fermentas, Hanover, MD, US).

\section{ELISA for measurment of IL-2}

Cells $\left(2 \times 10^{5}\right)$ were incubated in CM or FDM and stimulated with PHA for $3 \mathrm{~d}$. The supernatants were harvested and assayed for IL-2 production using an ELISA kit (Pierce Endogen, Rockford, IL, US) according to the manufacturer's instructions. Absorbance was measured at $450 \mathrm{~nm}$ by a MRX model ELISA reader (Dynatech Laboratories, Billinghurst, West Sussex, UK).
Immunofluorescence staining and flow cytometric analysis of bcl-2 and Fas/Apo-1/CD95

Harvested cells were incubated with fluorescein isothiocyanateconjugated monoclonal antibody to human bcl-2 and Fas/Apo1/CD95 (Ancell Bayport, MN, USA) for $30 \mathrm{~min}$ on ice and then washed three times; the cells were first fixed in $4 \%$ paraformaldehyde in PBS for $30 \mathrm{~min}$ on ice, followed by washing and resuspension in PBS. Samples were analysed by flow cytometry (Coulter Epics, Beckman Coulter, Miami, FL, USA).

\section{Western blot analysis}

Polyclonal antibodies against human p53 (Santa Cruz Biotechnology, Santa Cruz, CA, USA) were used in this study. Total cellular protein isolation and protein blotting were performed as previously described with slight modifications ( $\mathrm{Yu}$ et al. 2002; Liao et al. 2004). Total cellular protein $30 \mu \mathrm{g}$ was electrophoresed in $10 \%$ SDS-PAGE and transferred to a nitrocellulose membrane. The membrane was hydrated with p53 antibody. Protein blots were visualised by using an enhanced chemiluminescence substrate kit (Pierce, Rockford, IL, USA).

\section{Statistics}

Data were analysed to determine the statistical significance of differences between the control and folate-deficient groups by Student's paired $t$ test. Values $P<0.05$ were considered significant.

\section{Results}

\section{Kinetics of intracellular folate concentration}

Using chemiluminescent assay, the intracellular folate concentration in five normal human PBL in the resting phase (day 0) was $2.24 \mathrm{ng} / 10^{6}$ cells. When cells were cultured in FDM with PHA stimulation, the intracellular folate concentration dropped from $2.24(\mathrm{SD} 0.43)$ to $1(\mathrm{SD} 0.67) \mathrm{ng} / 10^{6}$ cells on day 3 , and to $2 \cdot 1$ (SD 0.56) $\mathrm{ng} / 10^{6}$ cells on day 9. In contrast, when PBL were cultured in $\mathrm{CM}$, the intracellular folate concentration increased from 2.24 (SD 0.43) to 6.31 (SD 2.74) ng/10 6 cells on day 3 , and to 40.94 (SD 13.07) ng/10 6 cells on day 9 (Table 1 ). The folate content of PHA-activated lymphocytes cultured in FDM did not respond to the same degree as that of the cells cultured in $\mathrm{CM}$; in contrast, it remained nearly as low as the level in the resting cells. The difference in folate level between the cells cultured in FDM and in CM reflected the relative folate deficiency in the cells cultured in FDM.

\section{Folate deficiency induces an accumulation of cells in $S$ phase}

The distribution of cell cycle phases for cells from control or folate-deficient cultures is shown in Fig. 1. A pronounced change in cell-cycling was observed in the folate-deficient culture, with an accumulation of cells in the $\mathrm{S}$ phase accompanied by a decrease in the proportion of cells in $\mathrm{G}_{0} / \mathrm{G}_{1}$ phase beginning from day 4 (Fig. 2). The percentage of cells entering $S$ phase was 1.9-2.2-fold higher in the folate-deficient culture than in the control culture on days 7-9. These data indicate that when human lymphocytes are cultured in FDM for at least $4 \mathrm{~d}$ and stimulated 
Table 1. Intracellular folate concentrations of human peripheral blood lymphocytes incubated with phytohaemagglutinin stimulation for the final $3 d$

\begin{tabular}{lccccc}
\hline & \multicolumn{4}{c}{ Folate concentration $\left(\mathrm{ng} / 10^{6}\right.$ cells) } \\
\cline { 2 - 5 } & \multicolumn{2}{c}{ Control culture $(n 5)$} & & \multicolumn{2}{c}{$\begin{array}{c}\text { Folate-deficient } \\
\text { culture }(n 5)\end{array}$} \\
\cline { 2 - 3 } & Mean & SD & & Mean & SD \\
\cline { 2 - 5 } Culture days & 2.24 & 0.43 & 2.24 & 0.43 \\
\hline 0 & 6.31 & 2.74 & 1.00 & 0.67 \\
4 & 16.45 & 3.15 & 1.63 & 0.85 \\
5 & 17.22 & 2.39 & 1.63 & 0.48 \\
6 & 26.64 & 6.43 & 1.55 & 0.53 \\
7 & 43.32 & 19.17 & 2.06 & 1.09 \\
8 & 47.22 & 19.46 & 1.93 & 0.36 \\
9 & 40.94 & 13.07 & 2.10 & 0.56 \\
\hline
\end{tabular}

\section{Control}

Cell cycle

Apoptosis

day 3

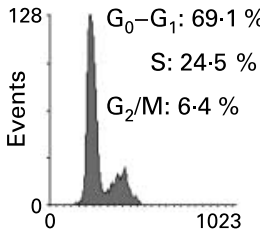

PMT4

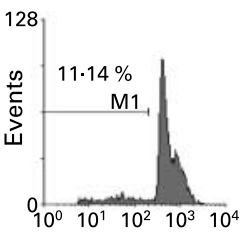

PMT4 LOG
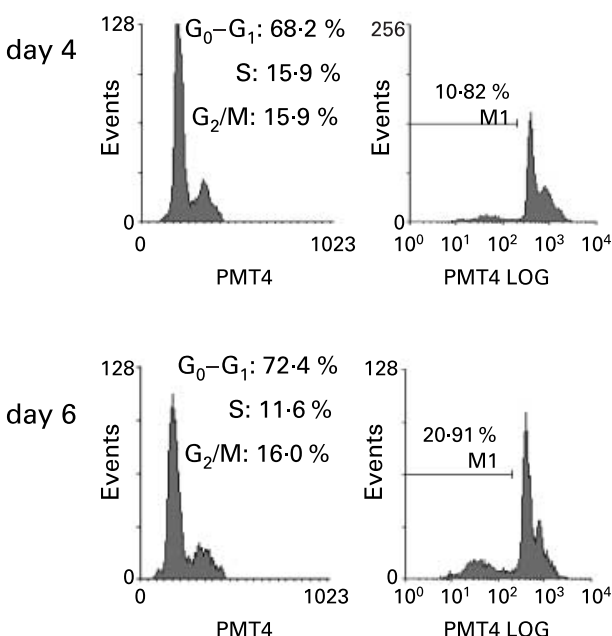

PMT4
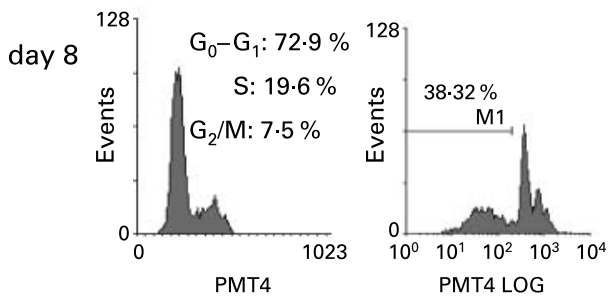

by PHA for at least $72 \mathrm{~h}$ in the final stage of culture, there is an associated accumulation of a large proportion of cells in $\mathrm{S}$ phase.

\section{Apoptosis in folate-deficient lymphocytes}

As shown in Fig. 1, the percentage of apoptosis was significantly increased in folate-deficient cells compared with controls. The difference began from day 4 and values remained significantly higher at all subsequent sampling intervals $(P<0 \cdot 05$; Fig. 3$)$.

Folate deficiency in lymphocytes downregulates $I L-2, b c l-2$ and Fas/Apo-1/CD95

As shown in Figs 4 and 5, IL-2, bcl-2 and Fas mRNA were downregulated in PHA-stimulated lymphocytes cultured in FDM compared with those in $\mathrm{CM}$ on day 3. bcl-2 and Fas protein

Folate deficiency
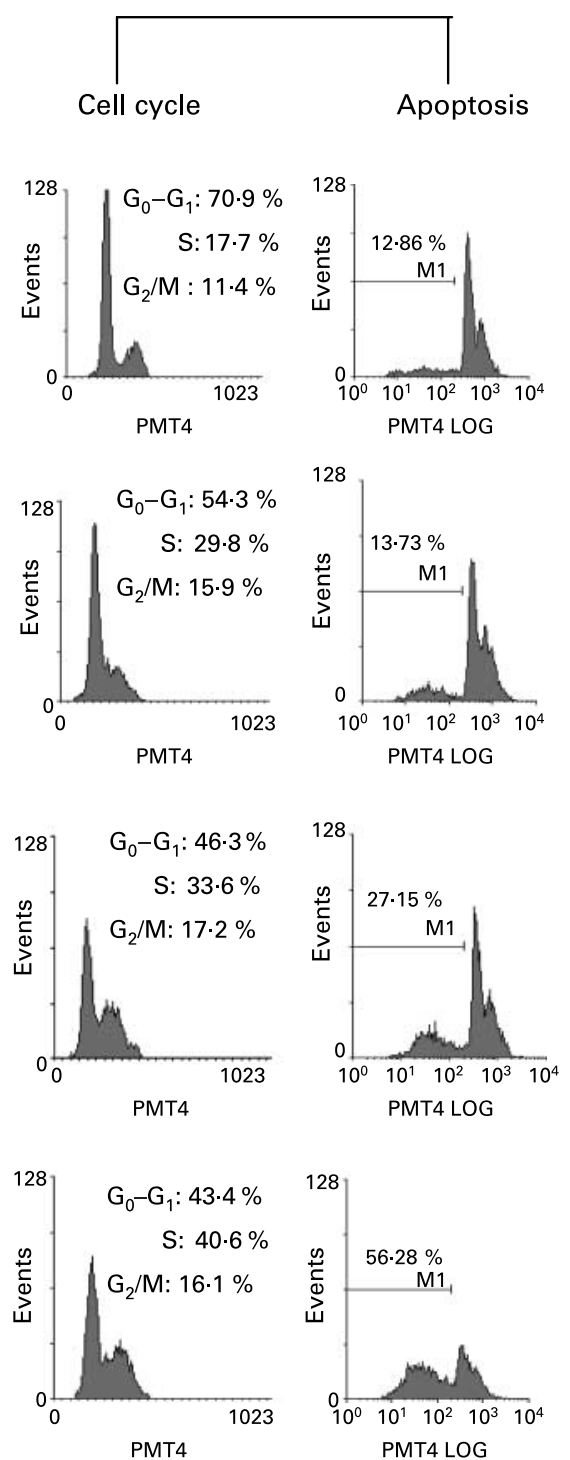

Fig. 1. Histogram of the cell cycle and apoptosis of phytohaemagglutinin-activated human lymphocytes. Cells were incubated in control medium or folate-deficient medium and stimulated by phytohaemagglutinin for the final $72 \mathrm{~h}$ prior to harvesting. Cells were harvested each day and then stained with propidium iodide for the cell cycle, and hypotonic fluorochrome propidium iodide containing solution for apoptosis, for $30 \mathrm{~min}$. Cellular DNA per $1 \times 10^{4}$ cells was analysed by flow cytometry. Fig. 1 is representative of eight similar experiments. 

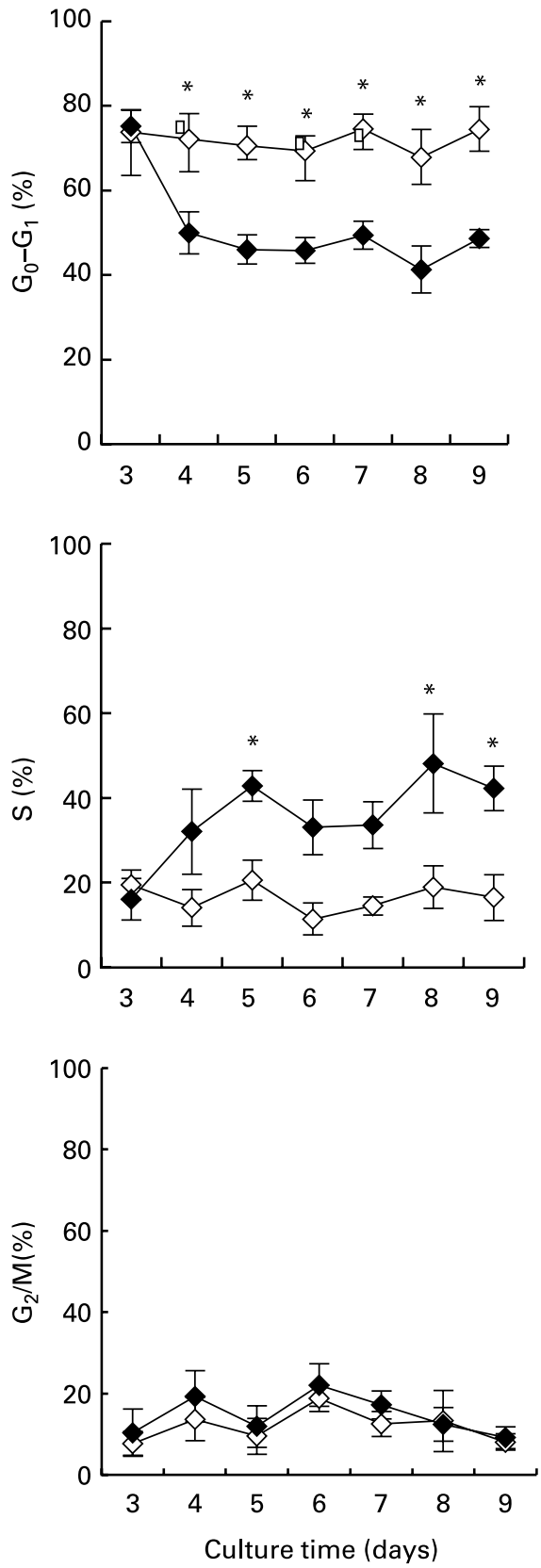

Fig. 2. Cell cycle analysis of phytohaemagglutinin-activated human peripheral blood lymphocytes. Cells were incubated in control medium $(\diamond)$ or folate-deficient medium $(\diamond)$ and stimulated by phytohaemagglutinin for the final $72 \mathrm{~h}$ before harvest. Cells were harvested each day and then stained with propidium iodide for $30 \mathrm{~min}$. Cellular DNA per $1 \times 10^{4}$ cells was analysed by flow cytometry. Data are means and standard deviations, $n 8$. ${ }^{*} P<0.05$ relative to control as evaluated by Student's $t$ test.

production was significantly lower in the folate-deficient culture relative to the control culture on day 6, as shown in Fig. 6.

\section{p53 protein expression during folate-deficient derived apoptosis}

As shown in Fig. 7, p53 protein expression was downregulated in PHA-stimulated lymphocytes cultured in FDM compared with $\mathrm{CM}$ on day 7. These data indicate that the apoptosis of folatedeficient human PBLs occurred independent of increased p53 expression.
Effects of folate, thymidine or hypoxanthine alone or combination of thymidine and hypoxanthine on apoptosis

Using the Annexin V assay, supplementation of the FDM with folic acid, thymidine or hypoxanthine alone, or a combination of thymidine and hypoxanthine, rescued folate-deficient lymphocytes from apoptosis on days 5 and 6 (Fig. 8). This indicated that a full rescue of the folate-deficient lymphocytes from apoptosis was achieved by folic acid at a concentration of $2 \mu \mathrm{M}$.

\section{Discussion}

The results of the present study demonstrate that folate-deficient lymphocytes accumulate in $\mathrm{S}$ phase rather than progressing through the cell cycle to $G_{0} / G_{1}$ phase, and that accumulation in $\mathrm{S}$ phase is clearly associated with the increased apoptosis of folate-deficient lymphocytes. Folate deficiency-induced apoptosis and $\mathrm{S}$ phase accumulation have also been reported in erythroblasts, various cell lines (Benito et al. 1996; Ingram et al. 1997; Huang et al. 1999) and PHA-stimulated primary human lymphocytes (Courtemanche et al. 2004). The mechanism whereby folate-deficient lymphocytes accumulate and undergo apoptosis in $\mathrm{S}$ phase is, however, unknown.

Although p53 proteins are thought to increase in response to diverse cellular stress and to sense genotoxic stress or DNA damage, we demonstrated in the present study that $\mathrm{p} 53$ protein is markedly downregulated rather than upregulated in the folatedeficient cells compared with the control cells on day 7. These results are consistent with independence from p53 for either the $S$ phase accumulation or the apoptosis of folate-deficient erythroblasts from $\mathrm{p} 53^{-1-}$ mice (Koury et al. 2000) and cell lines after treatment with specific inhibitors (Linke et al. 1996). p53 independence for either the $\mathrm{S}$ phase accumulation or apoptosis of folatedeficient, PHA-stimulated PBLs has not, however, been proposed.

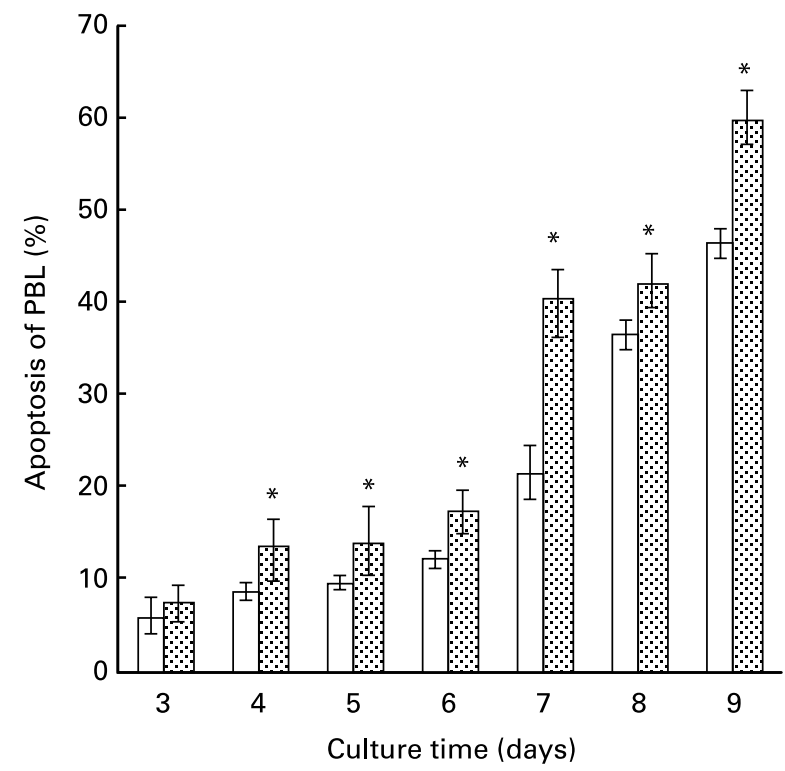

Fig. 3. Apoptosis of phytohaemagglutinin-activated human peripheral blood lymphocytes (PBL). Cells were incubated in control medium ( $\square$ ) or folate-

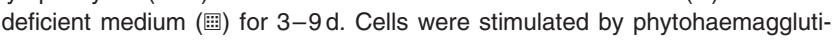
nin for the final $72 \mathrm{~h}$ prior to harvest and stained with propidium iodide. Data were analysed by flow cytometry. Values were the percentage of apoptotic cells (subdiploid propidium iodide staining). Data are means and standard deviations, $n 6$. ${ }^{*} P<0.05$ relative to control as evaluated by Student's $t$ test. 


\section{Control Folate deficiency}

bcl-2

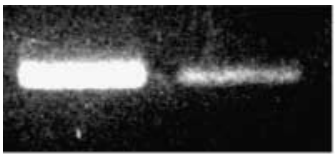

Fas

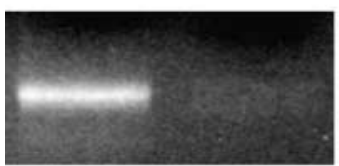

$\beta$-actin

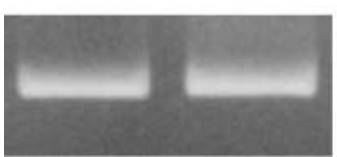

Control Folate deficiency

IL-2

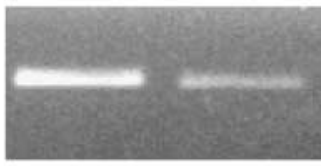

$\beta$-actin

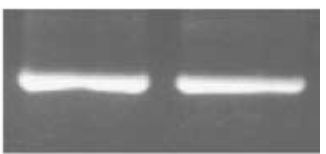

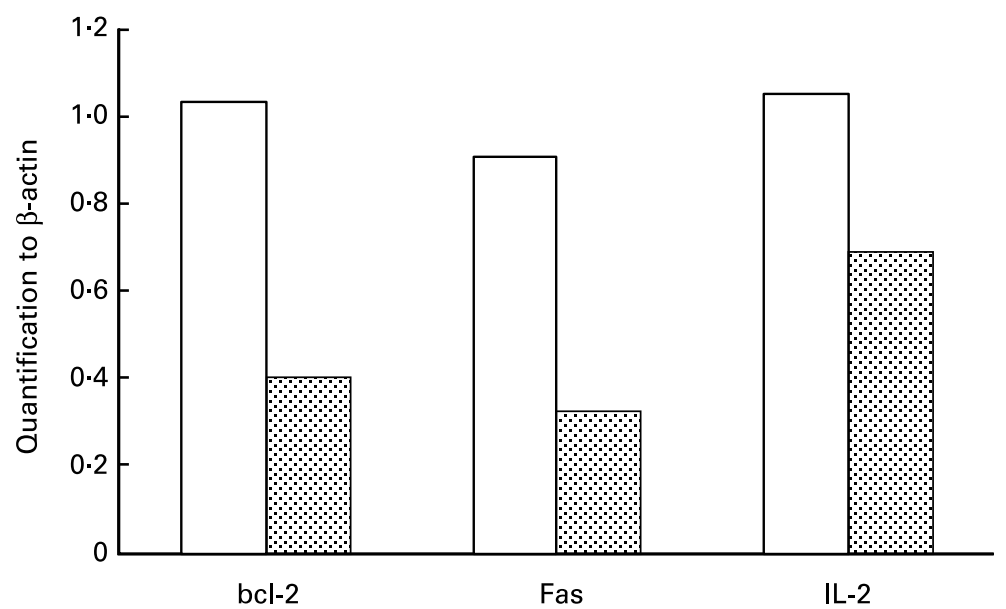

Fig. 4. The mRNA of IL-2, bcl-2 and Fas/Apo-1/CD95 expression in phytohaemagglutinin-activated human peripheral blood lymphocytes. Phytohaemagglutinin-

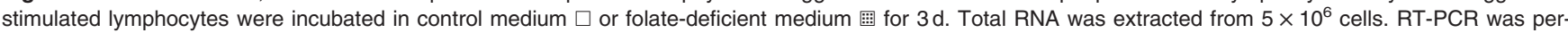
formed for mRNA of IL-2, bcl-2 and Fas/Apo-1/CD95. The message of amplification of IL-2, bcl-2, Fas/Apo-1/CD95 and $\beta$-actin was electrophoresed on agarose minigels and visualised with ethidium bromide staining. Densitometric quantification of these blots with normalisation to $\beta$-actin is shown in the graph.

It has been demonstrated that folate deficiency induces severe DNA damage, including massive uracil incorporation and chromosome breakage based on decreased thymidylate synthesis (Duthie \& Hawdon, 1998). Since intracellular 5,10-methylene tetrahydrofolate is the primary methyl donor for the de novo biosynthesis of dTMP from dUMP, folate deficiency results in an increased cellular dUMP:dTMP ratio. This increased ratio leads to an increase in the dUTP:dTTP ratio and finally increases the misincorporation of uracil into DNA (Wickramasinghe \& Fida, 1994; Benjamin et al. 1997; James et al. 2003). Furthermore, folatederived one-carbon groups are essential for the de novo synthesis of purines and pyrimidine, and dNTP are substrates for the DNA polymerase involved in DNA synthesis and repair. The fidelity of DNA synthesis is critically dependent on the current balance and availability of dNTP (Das et al. 1985).

Imbalances in the dNTP pool were noted in a variety of folatedeficient cells (van der Weyden et al. 1991; James et al. 1994; Oliver et al. 1997). Yoshioka and colleagues (1987) suggested that this dNTP pool imbalance could result in activation of the gene coding for an endonuclease, causing DNA double-strand breaks and cell death.
The relevance of dNTP pool alteration in cell death processes and the regulatory role of the salvage pathway of dNTP synthesis have been demonstrated (Lagergren \& Reichard, 1987). A similar role of the salvage pathway has been demonstrated in a variety of cells in which the addition of thymidine or a combination of two or three dNTP was sufficient to protect the cells from apoptosis. The results were, however, rather controversial (Oliver et al. 1997; Koury et al. 2000; Mashiyama et al. 2004). The results of the present study show that either folate, thymidine or hypoxanthine alone, or a combination of thymidine and hypoxanthine, could completely rescue cells from apoptosis. The cause of this discrepancy in results is unknown.

In addition to the downregulation of p53, folate deficiency was also found to downregulate IL-2, Fas and bcl-2 expression in terms of either mRNA or protein level. Fas is a proapoptotic molecule; its downregulation in the present study suggests that folate deficiency-induced apoptosis was not likely to occur via the Fas pathway. It has been shown that overexpression of the antiapoptotic gene bcl-2 protects cells from apoptosis induced by inhibitors of de novo dNTP synthesis (Miyashita \& Reed, 1992; Oliver et al. 1993), and that downregulation of bcl-2 induces 


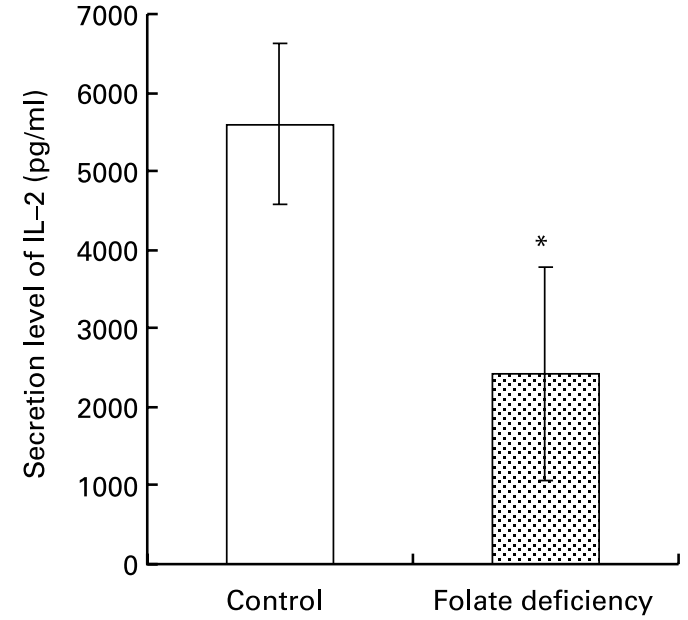

Fig. 5. Secretion of IL-2 by phytohaemagglutinin-activated human peripheral blood lymphocytes. Cells were incubated in control medium or folate-deficient medium and stimulated with phytohaemagglutinin. IL-2 secretion was analysed in the cell-free supernatant using ELISA and expressed as $\mathrm{pg} / \mathrm{ml}$. Mean values of IL-2 secretion in the supernatant of folate-deficient or control cells were 5599 (SD 1031) and 2418 (SD 1366) pg/ml, respectively $(n 7)$. ${ }^{\star} P<0.05$ relative to control as evaluated by Student's $t$ test.

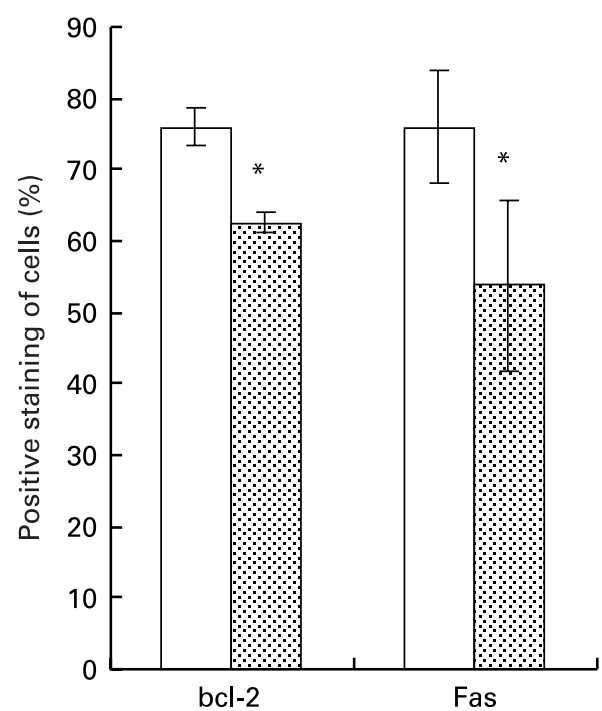

Fig. 6. Bcl-2 and Fas/Apo-1/CD95 expression in phytohaemagglutinin-activated human peripheral blood lymphocytes. Cells were incubated in control

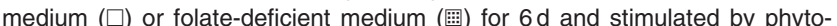
haemagglutinin for $48 \mathrm{~h}$ before harvesting. Cells were harvested and incubated with fluorescein isothiocyanate conjugated monoclonal antibody to human bcl-2 and Fas/ Apo-1/CD95 for $30 \mathrm{~min} .1 \times 10^{4}$ cells was analysed by flow cytometry. Data are means and standard deviations, $n 6$. ${ }^{*} P<0.05$ relative to control as evaluated by Student's $t$ test.

apoptosis (Fleischer et al. 2002). Although Oliver and collaborators described changes in dNTP metabolism that preceded DNA fragmentation in a model of apoptosis driven by deprivation of the cytokine IL-3 (Collins et al. 1992; Oliver et al. 1996, 1997), recent studies have shown that IL-2 deprivation also induces apoptosis through different mechanisms (Duke \& Cohen, 1986; Hildeman et al. 2002; Devireddy \& Green, 2003). As IL-2 is a known inducer of bcl-2 (Miyawaki et al. 1992), a downregulation of bcl-2, as in the present study, could be lane $\quad \begin{array}{llllll}1 & 2 & 3 & 4 & 5 & 6\end{array}$

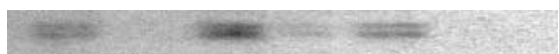

Fig. 7. The expression of p53 protein in phytohaemagglutinin-activated human peripheral blood lymphocytes. Phytohaemagglutinin-stimulated lymphocytes were incubated in control medium or folate-deficient medium for $7 \mathrm{~d}$ and stimulated by phytohaemagglutinin for $48 \mathrm{~h}$ before harvest. Total protein was extracted from $5 \times 10^{6}$ cells. The protein was electrophoresed in a $10 \%$ SDS-PAGE and transferred to nitrocellulose membrane. The membrane was hydrated with p53 antibody. Lanes 1, 3 and 5 are from control cells. Lanes 2, 4 , and 6 are from folate-deficient cells.

expected. These results suggest that IL-2 depletion by folate deficiency in lymphocytes reduces bcl-2 protein expression, thereby facilitating a dNTP pool imbalance and p53-independent triggered apoptosis.

These folate-deficient cells induced cell cycle arrest in S phase, cell apoptosis and reduced cell proliferation (data not shown). This change is probably also present in vivo. When folate deficiency is apparent in the peripheral blood, as in some populations in the world, the critical concentration of folate in resting PBL is able to meet the needs of the resting state, but once a critical situation occurs, for example a crisis of infection, it cannot meet the host's emerging needs. These data suggest that folate deficiency may affect the immune system by reducing the capacity of lymphocytes to proliferate and then differentiate into the effector cells that will remove the pathogen from the host in response to antigenic stimulation.

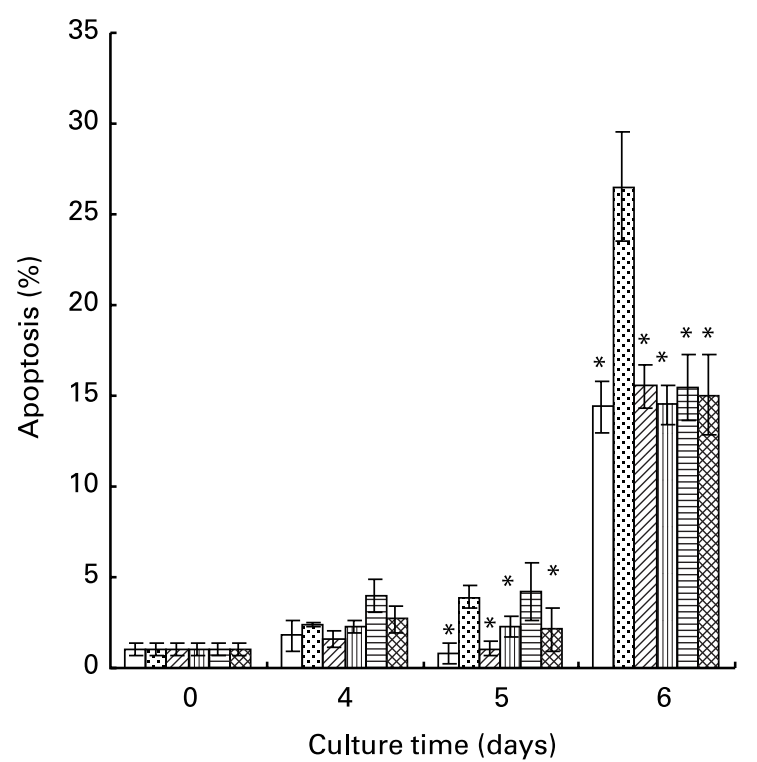

Fig. 8. Rescue of folate-deficient peripheral blood lymphocytes by folate, thymidine or hypoxanthine alone, or a combination of thymidine and hypoxanthine. Peripheral blood lymphocytes were cultured in folate-deficient medium (D) or control medium (C) stimulated by phytohaemagglutinin for the final $72 \mathrm{~h}$ prior to harvesting. At $\mathrm{O} \mathrm{h}$ of culture, folic acid $(\mathrm{F})(0.88 \mu \mathrm{g} / \mathrm{ml})$, thymidine $(\mathrm{T})(8.7 \mu \mathrm{g} / \mathrm{ml})$ or hypoxanthine $(\mathrm{H})(4.9 \mu \mathrm{g} / \mathrm{ml})$ alone, or a combination of thymidine and hypoxanthine $(\mathrm{H}+\mathrm{T})$, was added to the medium. At the indicated times, the cells were harvested. Apoptosis was determined by Annexin $\mathrm{V}$ assay. Values were the percentage of apoptotic cells (subdiploid fluorescein isothiocyanate-conjugated staining). Data are mean and standard deviations, $n 5$. ${ }^{*} P<0.05$ relative to folate deficiency as evaluated by Student's test. $\square$, C; 圆, D; 巡, F; 四, H; 目, T; $\otimes, H+T$. 


\section{Acknowledgements}

This study was supported by Grants NSC-89-2314-B-037-249 from National Science Council, Taiwan, ROC

\section{References}

Benito A, Silva M, Grillot D, Nunez G \& Fernandez-Luna JL (1996) Apoptosis induced by erythroid differentiation of human leukemia cell lines is inhibited by Bcl-XL. Blood 87, 3837-3843.

Benjamin CB, Matthew MM, Carol MW, James TMG, Robert AH, Wang GS, Wickramasinghe N, Richard BE \& Ames BN (1997) Folate deficiency causes uracil misincorporation into human DNA and chromosome breakage: implications for cancer and neuronal damage. Proc Natl Acad Sci USA 94, 3290-3295.

Bunout D, Petermann M, Hirsch S, de la Maza P, Suazo M, Barrera G \& Kauffman R (2000) Low serum folate but normal homocysteine levels in patients with atherosclerotic vascular disease and matched healthy controls. Nutr 16, 434-438

Collins MK, Marvel J, Malde P \& Lopez-Rivas A (1992) Interleukin 3 protects murine bone marrow cells from apoptosis induced by DNA damaging agents. J Exp Med 176, 1043-1051.

Courtemanche C, Huang AC, Elson-Schwab I, Kerry N, Ng BY \& Ames BN (2004) Folate deficiency and ionizing radiation cause DNA breaks in primary human lymphocytes: a comparison. FASEB $J \mathbf{1 8}$, 209-211.

Das SK, Kunkel TA \& Loeb LA (1985) Effects of altered nucleotide concentrations on the fidelity of DNA replication. Basic Life Sci 31, $117-126$.

Devireddy LR \& Green MR (2003) Transcriptional program of apoptosis induction following interleukin 2 deprivation: identification of $\mathrm{RC} 3$, a calcium/calmodulin binding protein, as a novel proapoptotic factor. Mol Cell Biol 23, 4532-4541.

Donehower LA \& Bradley A (1993) The tumor suppressor p53. Biochim Biophys Acta 1155, 181-205.

Duke RC \& Cohen JJ (1986) IL-2 addiction: withdrawal of growth factor activates a suicide program in dependent T cells. Lymphokine Res $\mathbf{5}$, 289-299.

Duthie SJ \& Hawdon A (1998) DNA instability (strand breakage, uracil misincorporation, and defective repair) is increased by folic acid depletion in human lymphocytes in vitro. FASEB J 12, 1491-1497.

Duthie SJ, Narayanan S, Brand GM, Pirie L \& Grant G (2002) Impact of folate deficiency on DNA stability. $J$ Nutr 132, S2444-S2449.

Fleischer A, Ayllon V, Dumoutier L, Renauld JC \& Rebollo A (2002) Proapoptotic activity of ITM2B(s), a BH3-only protein induced upon IL-2-deprivation which interacts with Bcl-2. Oncogene 21, 3181-3189.

Fleming A \& Copp AJ (1998) Embryonic folate metabolism and mouse neural tube defects. Science 280, 2107-2109.

Freudenheim JL, Graham S, Marshall JR, Haughey BP, Cholewinski S \& Wilkinson G (1991) Folate intake and carcinogenesis of the colon and rectum. Int J Epidemiol 20, 368-374.

Hildeman DA, Zhu Y, Mitchell TC, Kappler J \& Marrack P (2002) Molecular mechanisms of activated T cell death in vivo. Curr Opin Immunol 14, 354-359.

Huang RF, Ho YH, Lin HL, Wei JS \& Liu TZ (1999) Folate deficiency induces a cell cycle-specific apoptosis in HepG2 cells. J Nutr 129, 25-31

Ingram CF, Davidoff AN, Marais E, Sherman GG \& Mendelow BV (1997) Evaluation of DNA analysis for evidence of apoptosis in megaloblastic anaemia. Br J Haematol 96, 576-583.

James SJ, Miller BJ, McGarrity LJ \& Morris SM (1994) The effect of folic acid deficiency on deoxyribonucleotide pools and cell cycle distribution in mitogen-stimulated lymphocytes. Cell Prolif 27, 395-406.

James SJ, Pogribny IP, Pogribna M, Miller BJ, Jernigan S \& Melnyk S (2003) Mechanisms of DNA damage, DNA hypomethylation, and tumor progression in the folate/methyl-deficient rat model of hepatocarcinogenesis. J Nutr 133, S3740-S3747.
Kim YI, Shirwadkar S, Choi SW, Puchyr M, Wang Y \& Mason JB (2000) Effects of dietary folate on DNA strand breaks within mutation-prone exons of the p53 gene in rat colon. Gastroenterology 119, 151-161.

Koury MJ, Price JO \& Hicks GG (2000) Apoptosis in megaloblastic anemia occurs during DNA synthesis by a p53-independent, nucleoside-reversible mechanism. Blood 96, 3249-3255.

Kuerbitz SJ, Plunkett BS, Walsh WV \& Kastan MB (1992) Wild-type p53 is a cell cycle checkpoint determinant following irradiation. Proc Natl Acad Sci USA 89, 7491-7495.

Lagergren J \& Reichard P (1987) Purine deoxyribonucleosides counteract effects of hydroxyurea on deoxyribonucleoside triphosphate pools and DNA synthesis. Biochem Pharmacol 36, 2985-2991.

Liao WT, Chang KL, Yu CL, Chen GS, Chang LW \& Yu HS (2004) Arsenic induces human keratinocyte apoptosis by the Fas/Fas ligand pathway, which correlates with alterations in nuclear factor-Kb and activator protein-1 activity. J Invest Dermatol 122, 125-129.

Linke SP, Clarkin KC, Di Leonardo A, Tsou A \& Wahl GM (1996) A reversible, p53-dependent G0/G1 cell cycle arrest induced by ribonucleotide depletion in the absence of detectable DNA damage. Genes Dev. 10, 934-947.

Lowe SW, Schmitt EM, Smith SW, Osborne BA \& Jacks T (1993) p53 is required for radiation-induced apoptosis in mouse thymocytes. Nature 362, 847-849.

Maltzman W \& Czyzyk L (1984) UV irradiation stimulates levels of p53 cellular tumor antigen in nontransformed mouse cells. Mol Cell Biol 4 , 1689-1694.

Mashiyama ST, Courtemanche C, Elson-Schwab I, Crott J, Lee BL, Ong CN, Fenech M \& Ames BN (2004) Uracil in DNA, determined by an improved assay, is increased when deoxynucleosides are added to folate-deficient cultured human lymphocytes. Anal Biochem 330 , $58-69$.

Michalis LK, Pappas K, Tweddel A, Kolaitis N, Katsouras CS, Loukas S, Goudevenos J, Bourantas K \& Sideris DA (2001) Relatively low red cell folate levels and acute coronary syndromes. Coron Artery Dis 12, 665-668.

Miyashita T \& Reed JC (1992) bcl-2 gene transfer increases relative resistance of S49.1 and WEHI7.2 lymphoid cells to cell death and DNA fragmentation induced by glucocorticoids and multiple chemotherapeutic drugs. Cancer Res 52, 5407-5411.

Miyawaki T, Uehara T, Nibu R, Tsuji T, Yachie A, Yonehara S \& Taniguchi N (1992) Differential expression of apoptosis-related Fas antigen on lymphocyte subpopulations in human peripheral blood. $J$ Immunol 149, 3753-3758.

Oliver FJ, Collins MK \& Lopez-Rivas A (1996) Regulation of the salvage pathway of deoxynucleotides synthesis in apoptosis induced by growth factor deprivation. Biochem J 316, 421-425.

Oliver FJ, Collins MK \& Lopez-Rivas A (1997) Overexpression of a heterologous thymidine kinase delays apoptosis induced by factor deprivation and inhibitors of deoxynucleotide metabolism. J Biol Chem 272, 10624-10630.

Oliver FJ, Marvel J, Collins MK \& Lopez-Rivas A (1993) Bcl-2 oncogene protects a bone marrow-derived pre-B-cell line from $5^{\prime}$-fluor, $2^{\prime}$-deoxyuridine-induced apoptosis. Biochem Biophys Res Commun 194, $126-132$.

Pogribny IP, Basnakian AG, Miller BJ, Lopatina NG, Poirier LA \& James SJ (1995) Breaks in genomic DNA and within the p53 gene are associated with hypomethylation in livers of folate/methyl-deficient rats. Cancer Res 55, 1894-1901.

Rosenberg IH \& Mason JB (1989) Folate, dysplasia, and cancer. Gastroenterology 97, 502-503.

Shane B \& Stokstad EL (1985) Vitamin B12-folate interrelationships. Annu Rev Nutr 5, 115-141.

Smithells RW, Sheppard S \& Schorah CJ (1976) Vitamin deficiencies and neural tube defects. Arch Dis Child 51, 944-950.

Strasser A, Harris AW, Jacks T \& Cory S (1994) DNA damage can induce apoptosis in proliferating lymphoid cells via p53-independent mechanisms inhibitable by Bcl-2. Cell 79, 329-339. 
van der Weyden MB, Hayman RJ, Rose IS \& Brumley J (1991) Folatedeficient human lymphoblasts: changes in deoxynucleotide metabolism and thymidylate cycle activities. Eur J Haematol 47, 109-114.

Wickramasinghe SN \& Fida S (1994) Bone marrow cells from vitamin B12- and folate-deficient patients misincorporate uracil into DNA. Blood 83, 1656-1661.

Yoshioka A, Tanaka S, Hiraoka O, Koyama Y, Hirota Y, Ayusawa D, Seno T, Garrett C \& Wataya Y (1987) Deoxyribonucleoside triphosphate imbalance. 5-Fluorodeoxyuridine-induced DNA double strand breaks in mouse FM3A cells and the mechanism of cell death. J Biol Chem 262, 8235-8241.

Yu HS, Liao WT, Chang KL, Yu CL \& Chen GS (2002) Arsenic induces TNF- $\alpha$ release and tumor necrosis factor receptor-1 signaling in T-helper cell apoptosis. J Invest Dermatol 119, 812-819.

Zambetti GP \& Levine AJ (1993) A comparison of the biological activities of wild-type and mutant p53. FASEB $J$ 7, 855-865. 